\title{
GROUNDWATER QUALITY ASSESSMENT FOR DRINKING PURPOSE IN SOUTH-EASTERN PART OF PANCHKULA CITY, HARYANA, INDIA
}

\author{
Anup Kumar ${ }^{1 *}$, Shishupal Singh ${ }^{2}$ and V.S. Arya $^{3}$ \\ ${ }^{1}$ Front Office-HARSAC, Panchkula, India \\ ${ }^{2}$ Govt. ITI, Panchkula, India \\ ${ }^{3}$ Haryana Space Applications Centre (HARSAC), Hisar, India
}

Received on: 01.07.2020

Revised on: 21.07 .2020

Accepted on: 25.07 .2020

\begin{abstract}
Water is a precious natural resource available on the planet Earth. About two third is water on the planet Earth but the usable water mainly for drinking purpose is very less. Fast developmental activities have put pressure on surface water and groundwater. Groundwater is highly important for drinking, agriculture and industrial purposes in the world. Groundwater quality plays an important role for drinking purpose. Many diseases like fluorosis, methemoglobinemia, arsenocosis are due to poor quality of drinking water. In urban areas, groundwater quality is deteriorated due to solid and liquid wastes disposal. The present study has been carried out to assess groundwater quality for drinking purpose in south-eastern part of Panchkula city, Haryana. In the present study eight groundwater samples were collected in the month of June 2019 from different locations in the study area. Groundwater samples were analyzed using Field Water Testing Kit prepared by Tamilnadu Water Supply and Drainage Board (TWAD), Chennai for ten chemical parameters-pH,hardness, chloride, fluoride, iron, ammonia, nitrate, nitrite, phosphate and residual chlorine. Chemical analysis of groundwater samples show that in the groundwater samples $\mathrm{pH}$ ranges-7 to 7.5 , hardness $100 \mathrm{mg} / \mathrm{l}$ to $250 \mathrm{mg} / \mathrm{l}$, chloride $40 \mathrm{mg} / \mathrm{l}$ to $110 \mathrm{mg} / \mathrm{l}$, fluoride $0.5 \mathrm{mg} / \mathrm{l}$ to $1 \mathrm{mg} / \mathrm{l}$, iron nil, ammonia nil to $3 \mathrm{mg} / \mathrm{l}$, nitrite $0.2 \mathrm{mg} / \mathrm{l}$ to $0.5 \mathrm{mg} / \mathrm{l}$, nitrate $20 \mathrm{mg} / \mathrm{l}$ to $75 \mathrm{mg} / \mathrm{l}$, phosphate nil to $1 \mathrm{mg} / \mathrm{l}$, residual chlorine nil to $0.2 \mathrm{mg} / \mathrm{l}$. As per BIS drinking water standards $\mathrm{pH}$, chloride, fluoride, iron, nitrite, phosphate, residual chlorine is desirable in all the eight groundwater samples; hardness is desirable in four groundwater samples and permissible in four groundwater samples; ammonia is desirable in six groundwater samples and non-potable in two groundwater samples; nitrate is desirable in seven groundwater samples and non-potable in one groundwater sample. Groundwater quality at Govt. Primary School, Ramgarh, Govt. Senior Secondary School, Ramgarh and Sector-28-C, Panchkula is desirable and at Market Ramgarh, Sector-25, Panchkula, Sector-28-A, Panchkula, Sector-28-B, Panchkula is permissible and Sector-26, Panchkula is non-potable. The study gives a scenario of groundwater quality for drinking purpose in the study area. The study can be used for monitoring groundwater quality for drinking purpose.
\end{abstract}

\section{Keywords}

Groundwater, quality, assessment, drinking, Ramgarh, Panchkula, Haryana

\section{Introduction}

Water is important for survival of living beings. In the present developmental activities water resources are under stress due to utilization for drinking, irrigation and industrial purposes. Groundwater is vulnerable to anthropogenic activities wherever it is shallow and exploitation wherever there is high population pressure. In the present scenario it becomes necessary to have check on the industries polluting the groundwater as well as wise use of water in each sector. Further, in urban and semi-urban areas groundwater is under 
severe exploitation for drinking and industrial purposes which lead to pollution and decline of groundwater level.Abbulu and Srinivasa Rao (2013), Agrawal (2009), Deshpande and Aher (2012), Madhav et al. (2018), Tripathi etal. (2012), Zidi et al. (2017) had done work on groundwater quality assessment of urban areas. Here, the main objective of the study was to assess groundwater quality for drinking purpose in the study areas as discussed below.

\section{Study area}

The study area comprises of south-eastern part of Panchkula city (Sector 25, Sector-26, 27, 28, 29, 30 of Panchkula cityand Ramgarh town).The geo-coordinates of the study area are latitude $30.64^{\circ} \mathrm{N}$ to $30.68^{\circ} \mathrm{N}$ and longitude $76.87^{\circ} \mathrm{E}$ to $76.89^{\circ}$ E and covers $32.49 \mathrm{Km}^{2}$ area (Fig.1).

Collection of samples and analysis

Eight groundwater samples were collected in plastic $250 \mathrm{ml}$ bottles during June 2019. Location of groundwater samples were marked using mobile GPS. All the eight groundwater

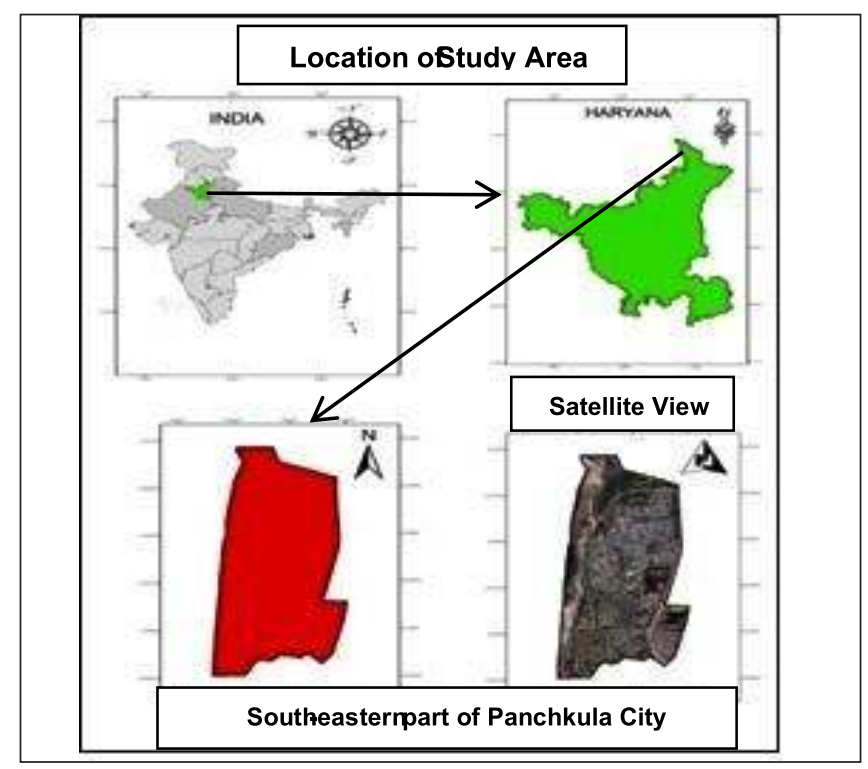

Figure 1: Location map of the study area.

Table 1: Groundwater samples location.

\begin{tabular}{|l|l|l|l|l|}
\hline S. No. & Location & Source & Latitude & Longitude \\
\hline 1 & Govt. Primary School, Ramgarh & Tube Well & $30^{\circ} 39^{\prime} 2.65^{\prime \prime} \mathrm{N}$ & $76^{\circ} 53^{\prime} 20.04^{\prime \prime} \mathrm{E}$ \\
\hline 2 & Govt. Senior Secondary School, Ramgarh & Tube Well & $30^{\circ} 38^{\prime} 48.85^{\prime \prime} \mathrm{N}$ & $76^{\circ} 53^{\prime} 5.54^{\prime \prime} \mathrm{E}$ \\
\hline 3 & Market, Ramgarh & Tube Well & $30^{\circ} 38^{\prime} 44.20^{\prime \prime} \mathrm{N}$ & $76^{\circ} 53^{\prime} 3.10^{\prime \prime} \mathrm{E}$ \\
\hline 4 & Sector 28-A, Panchkula & Tube Well & $30^{\circ} 38^{\prime} 47.89^{\prime \prime} \mathrm{N}$ & $76^{\circ} 52^{\prime} 57.88^{\prime \prime} \mathrm{E}$ \\
\hline 5 & Sector 28-B, Panchkula & Tube Well & $30^{\circ} 38^{\prime} 52.81^{\prime \prime} \mathrm{N}$ & $76^{\circ} 52^{\prime} 53.38^{\prime \prime} \mathrm{E}$ \\
\hline 6 & Sector-28-C, Panchkula & Hand pump & $30^{\circ} 38^{\prime} 48.35^{\prime \prime} \mathrm{N}$ & $76^{\circ} 52^{\prime} 33.65^{\prime \prime} \mathrm{E}$ \\
\hline 7 & Sector-26, Panchkula & Tube Well & $30^{\circ} 39^{\prime} 27.41^{\prime \prime} \mathrm{N}$ & $76^{\circ} 52^{\prime} 51.02^{\prime \prime} \mathrm{E}$ \\
\hline 8 & Sector-25, Panchkula & Tube Well & $30^{\circ} 40^{\prime} 7.40^{\prime \prime} \mathrm{N}$ & $76^{\circ} 52^{\prime} 38.96^{\prime \prime} \mathrm{E}$ \\
\hline
\end{tabular}

samples were analyzed using Field Water Testing Kit prepared by Tamil Nadu Water Supply and Drainage Board (TWAD), Chennai for $\mathrm{pH}$, hardness, chloride, fluoride, iron, nitrite, nitrate, ammonia, phosphate and residual chlorine. The results of chemical analysis of groundwater samples were put in MS Excel and bar graphs of each chemical parameter were prepared. Results were interpreted in comparison with BIS (IS 10500:2012) drinking water standards.

Table 2: Results of groundwater samples analysis.

\begin{tabular}{|c|c|c|c|c|c|c|c|c|c|c|c|c|}
\hline S. No. & $\begin{array}{l}\text { Sample } \\
\text { Locations }\end{array}$ & Source & $\mathrm{pH}$ & $\begin{array}{c}\text { Hardness } \\
(\mathrm{mg} / \mathrm{l})\end{array}$ & $\begin{array}{l}\text { Chloride } \\
\text { (mg/) }\end{array}$ & $\begin{array}{l}\text { Fluoride } \\
(\mathrm{mg} /)\end{array}$ & $\begin{array}{l}\text { Iron } \\
(\mathrm{mg} / \mathrm{l})\end{array}$ & $\begin{array}{c}\text { Ammonia } \\
(\mathrm{mg} / \mathrm{l})\end{array}$ & $\begin{array}{l}\text { Nitrite } \\
(\mathrm{mg} /)\end{array}$ & $\begin{array}{l}\text { Nitrate } \\
(\mathrm{mg} / \mathrm{l})\end{array}$ & $\begin{array}{c}\text { Phosphate } \\
(\mathrm{mg} / \mathrm{l})\end{array}$ & $\begin{array}{c}\text { Residual } \\
\text { Chlorine } \\
(\mathrm{mg} / \mathrm{l})\end{array}$ \\
\hline 1 & $\begin{array}{l}\text { Govt. Primary } \\
\text { School, Ramgarh }\end{array}$ & Tubewell & 7.5 & 180 & 40 & 0.5 & 0.0 & 0.5 & 0.5 & 45 & 0.5 & 0.0 \\
\hline 2 & $\begin{array}{l}\text { Govt. Senior } \\
\text { Secondary School, } \\
\text { Ramgarh }\end{array}$ & Tubewell & 7.5 & 100 & 40 & 0.5 & 0.0 & 0.0 & 0.5 & 45 & 0.0 & 0.0 \\
\hline 3 & $\begin{array}{l}\text { Sector-28-A, } \\
\text { Panchkula }\end{array}$ & Tubewell & 7.0 & 250 & 40 & 0.0 & 0.0 & 0.5 & 0.2 & 45 & 0.5 & 0.0 \\
\hline 4 & $\begin{array}{l}\text { Sector-28-B, } \\
\text { Panchkula }\end{array}$ & Tubewell & 7.0 & 250 & 40 & 0.0 & 0.0 & 0.5 & 0.2 & 45 & 0.5 & 0.0 \\
\hline 5 & $\begin{array}{l}\text { Sector-28-C, } \\
\text { Panchkula }\end{array}$ & Handpump & 7.5 & 200 & 110 & 1.0 & 0.0 & 3.0 & 0.2 & 20 & 0.5 & 0.2 \\
\hline
\end{tabular}




\begin{tabular}{|l|l|c|c|c|c|c|c|c|c|c|c|c|}
\hline 6 & $\begin{array}{l}\text { Sector-26, } \\
\text { Panchkula }\end{array}$ & Tubewell & 7.5 & 140 & 40 & 0.5 & 0.0 & 1.0 & 0.2 & 75 & 1.0 & 0.0 \\
\hline 7 & $\begin{array}{l}\text { Sector-25, } \\
\text { Panchkula }\end{array}$ & Tubewell & 7.0 & 240 & 40 & 0.0 & 0.0 & 0.5 & 0.5 & 45 & 0.0 & 0.0 \\
\hline 8 & $\begin{array}{l}\text { Market, } \\
\text { Ramgarh }\end{array}$ & Tubewell & 7.0 & 250 & 40 & 0.5 & 0.0 & 0.0 & 0.5 & 45 & 1.0 & 0.0 \\
\hline
\end{tabular}

Note: A,B,C represent the three sample locations in Sector-28,Panchkula, not the Sector-28A,28B and 28C.

Table 3: BIS Drinking Water Standards (IS 10500:2012)

\begin{tabular}{|l|l|c|c|c|}
\hline S. No. & Constituent & \multicolumn{2}{|c|}{ Potable } & Non-Potable \\
\hline & & Desirable & Permissible & \\
\hline 1 & $\mathrm{pH}$ & 6.5 to 8.5 & - & $<6.5$ to $>8.5$ \\
\hline 2 & Total Hardness (mg/l) & $<200$ & $200-600$ & $>600$ \\
\hline 3 & Chloride (mg/l) & $<250$ & $250-1000$ & $>1000$ \\
\hline 4 & Fluoride (mg/l) & $<1.0$ & $1.0-1.5$ & $>1.5$ \\
\hline 5 & Iron (mg/l) & $<0.3$ & - & $>0.3$ \\
\hline 6 & Ammonia (mg/l) & $<0.5$ & - & $>0.5$ \\
\hline 7 & Nitrite (mg/l) & $<1.0$ & - & $>1.0$ \\
\hline 8 & Nitrate (mg/l) & $<45$ & - & $>45$ \\
\hline 9 & Phosphate (mg/l) & $<1.0$ & $0.2-1$ & $>1.0$ \\
\hline 10 & Residual Chlorine (mg/l) & $<0.2$ & \\
\hline
\end{tabular}

\section{RESULTS AND DISCUSSION}

pH

In the study area, $\mathrm{pH}$ varied from 7 to 7.5 and desirable in all eight groundwater samples (Fig.2).

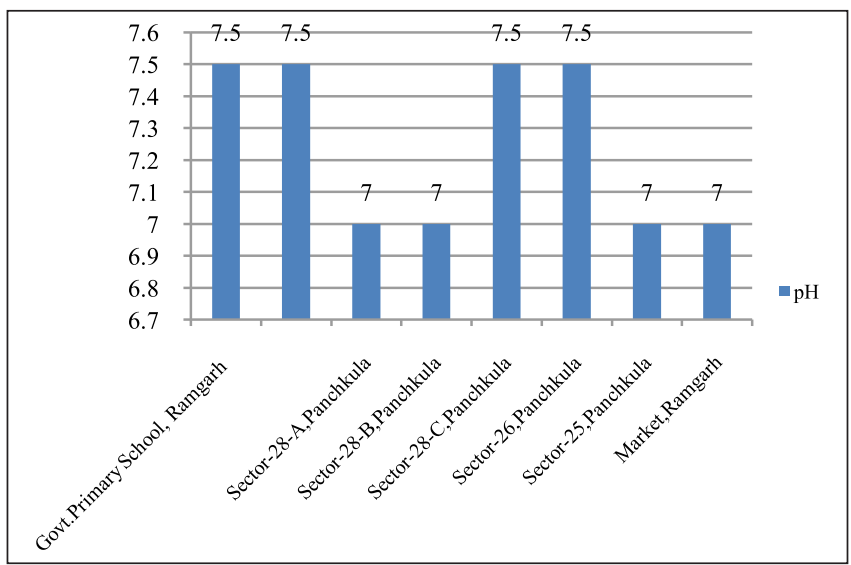

Figure 2:pH in groundwater samples.

\section{Hardness}

Hardness varied from $100 \mathrm{mg} / \mathrm{l}$ to $250 \mathrm{mg} / \mathrm{l}$ in the study area. Hardness in groundwater samples was desirable at Govt. Primary School Ramgarh (180 mg/l), Govt. Senior Secondary School Ramgarh (100 mg/l), Sector-28-C, Panchkula (200 mg/l), Sector-26, Panchkula (140 mg/l) and permissible at Sector-28-A, Panchkula (250 mg/l), Sector28-B, Panchkula (250 mg/l), Sector- 25 (240 mg/l) and Market Ramgarh (250 mg/l) (Fig.3).

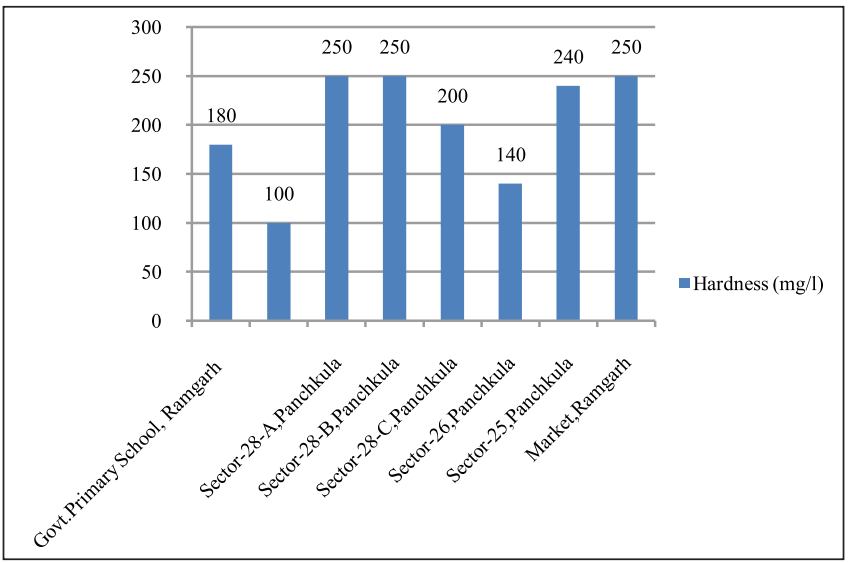

Figure 3: Hardness in groundwater samples.

\section{Chloride}

Chloride was present in range from $40 \mathrm{mg} / \mathrm{l}$ to $110 \mathrm{mg} / \mathrm{l}$ in the study area. Chloride in groundwater samples was within desired limits in all eight groundwater samples (Fig. 4).

\section{Fluoride}

Fluoride had values from $0.5 \mathrm{mg} / \mathrm{l}$ to $1 \mathrm{mg} / \mathrm{l}$ in the study area, thus being within desirable limits in all eight groundwater samples (Fig. 5). 


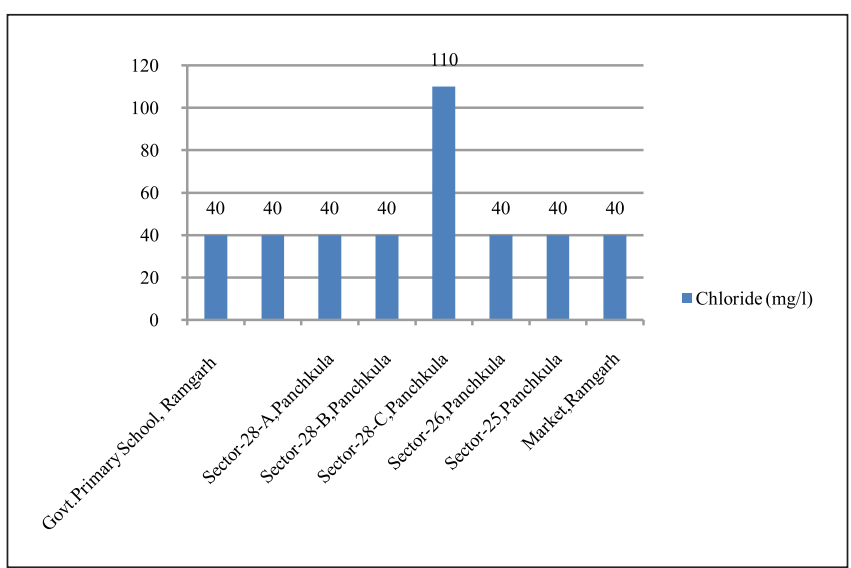

Figure 4: Chloride in groundwater samples.

\section{Iron}

Iron was absent in all eight groundwater samples, hence, desirable for drinking purpose (Fig.6).

\section{Ammonia}

Ammonia varied over nil to $3 \mathrm{mg} / \mathrm{l}$ in the study area. Ammonia was in prescribed values atGovt. Primary School,

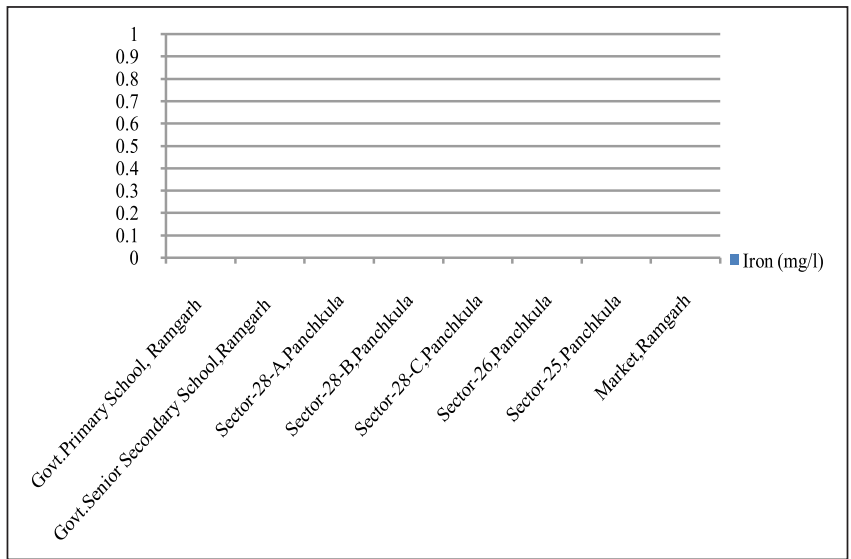

Figure 6: Iron in groundwater samples.

\section{Nitrite}

Nitrite varied from $0.2 \mathrm{mg} / \mathrm{l}$ to $0.5 \mathrm{mg} / \mathrm{l}$ in the study area, desirable for drinking purpose in all eight groundwater samples (Fig.8).

\section{Nitrate}

Nitrate varies from $20 \mathrm{mg} / \mathrm{l}$ to $75 \mathrm{mg} / \mathrm{l}$ in the study area, desirable in seven groundwater samples and non-potable in Sector-26 (75 mg/l) groundwater sample (Fig.9).

\section{Phosphate}

Phosphate was present over nil to $1 \mathrm{mg} / \mathrm{l}$ in the study area, thus at desirable values in all eight groundwater samples (Fig.10).

\section{Residual Chlorine}

Residual Chlorine had values from nil to $0.2 \mathrm{mg} / \mathrm{l}$ in the study area (desirable) (Fig.11).

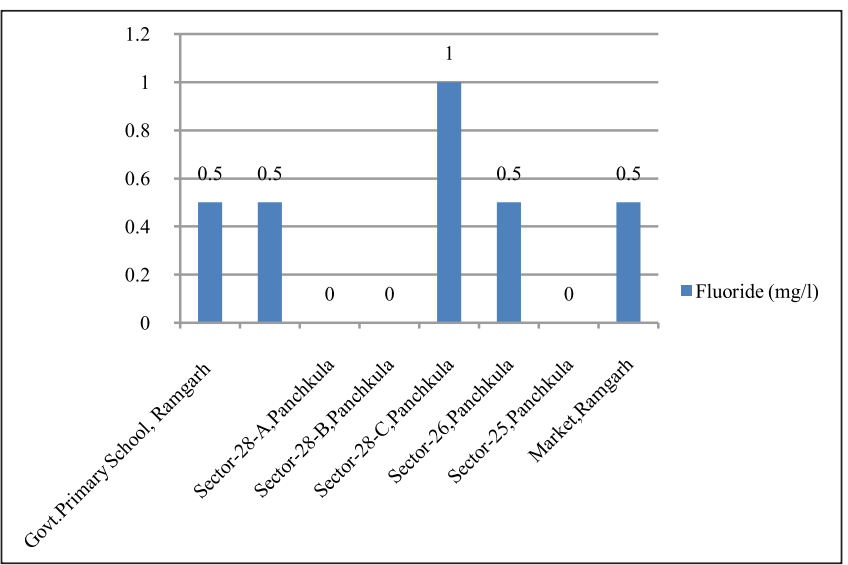

Figure 5: Fluoride in groundwater samples.

Ramgarh (0.5 mg/l), Govt. Senior Secondary School Ramgarh (0.0 mg/l), Sector- 28-A, Panchkula (0.5 mg/l), Sector- 28-B, Panchkula (0.5 mg/l), Sector- 25, Panchkula (0.5 mg/l), Market Ramgarh (0.0 mg/l) and non-potable at Sector-28-C, Panchkula (3.0 mg/l) and Sector-26, Panchkula (1 mg/l) (Fig.7).

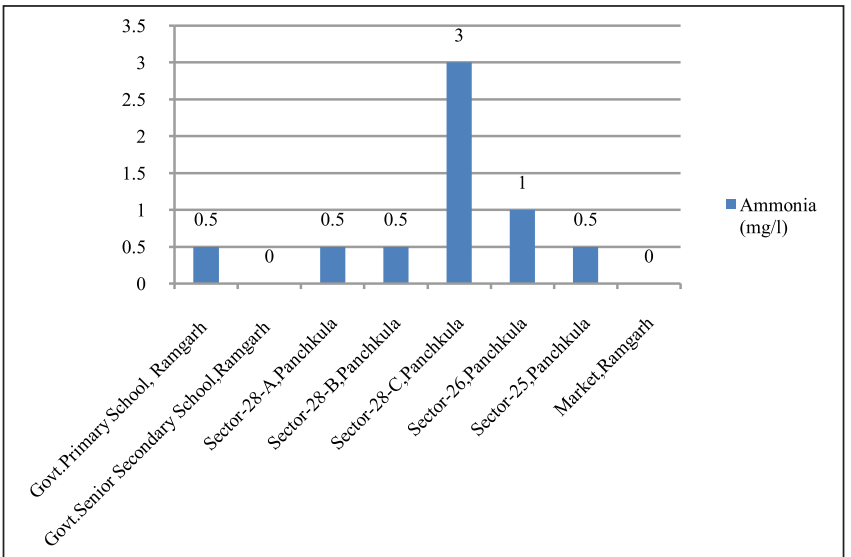

Figure 7: Ammonia in groundwater samples.

\section{Groundwater quality at sample sites}

Groundwater Quality at Govt. Primary School, Ramgarh In groundwater sample collected at Govt. Primary School, Ramgarh, the various chemical drinking water parameters studied were found to be withindesirable limits (Fig.12).

\section{Groundwater quality at Govt. Senior Secondary School,} Ramgarh

In groundwater sample collected at Govt. Senior Secondary School, Ramgarh chemical drinking water parameters were in desirable limits (Fig.13).

\section{Groundwater quality at Market, Ramgarh}

In groundwater sample collected at Market Ramgarh analyzed chemical drinking water parameters $\mathrm{pH}$, chloride, fluoride, iron, ammonia, nitrite, nitrate, phosphate, residual 


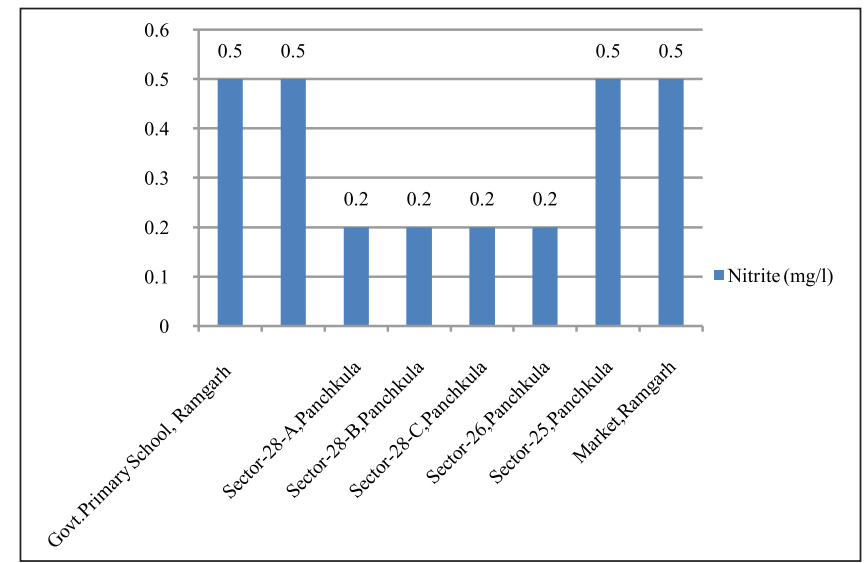

Figure 8: Nitrite in groundwater samples.

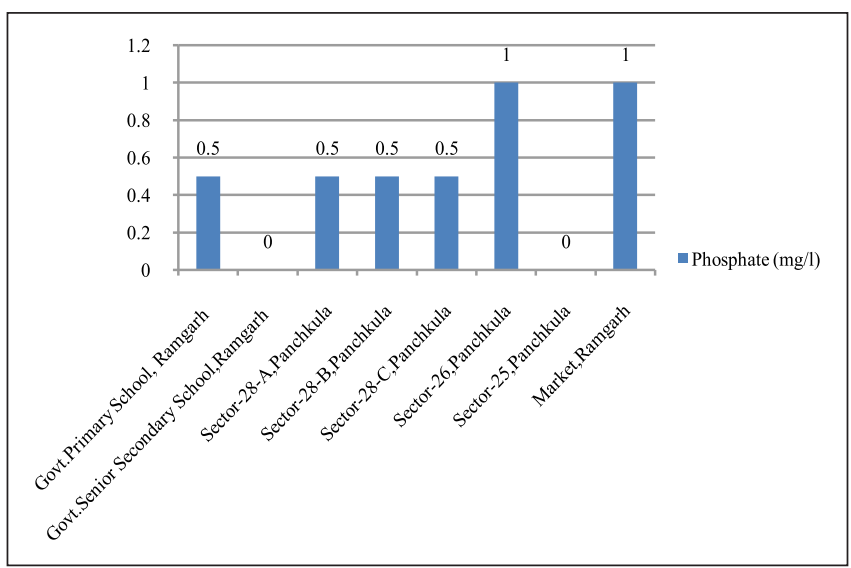

Figure 10: Phosphate in groundwater samples.

chlorine were in values as permissible for drinking water (Fig.14).

\section{Groundwater quality at Sector-25, Panchkula}

In groundwater sample collected at Sector-25, Panchkula the $\mathrm{pH}$, chloride, fluoride, iron, nitrite, ammonia, nitrate, phosphate, residual chlorine parameters adhered to permissible drinking water limits (Fig.15).

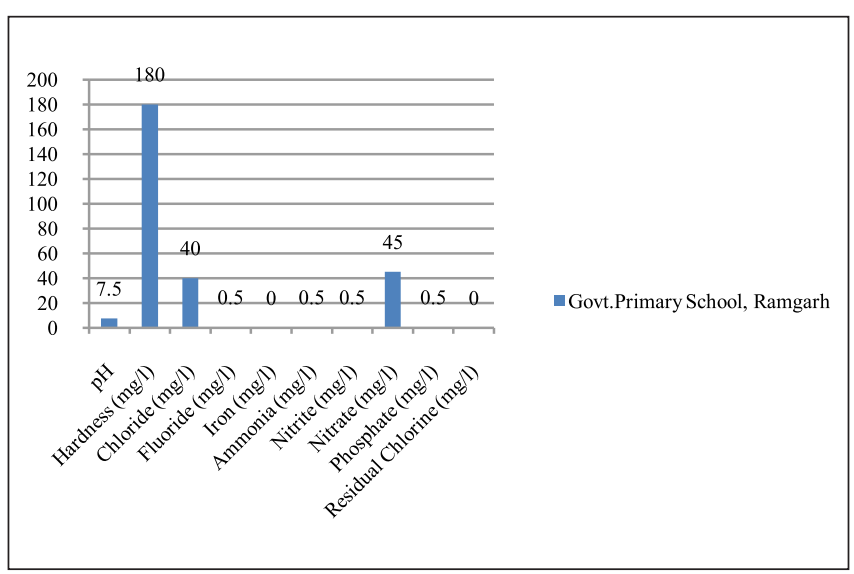

Figure 12: Groundwater quality at Govt. Primary School, Ramgarh.

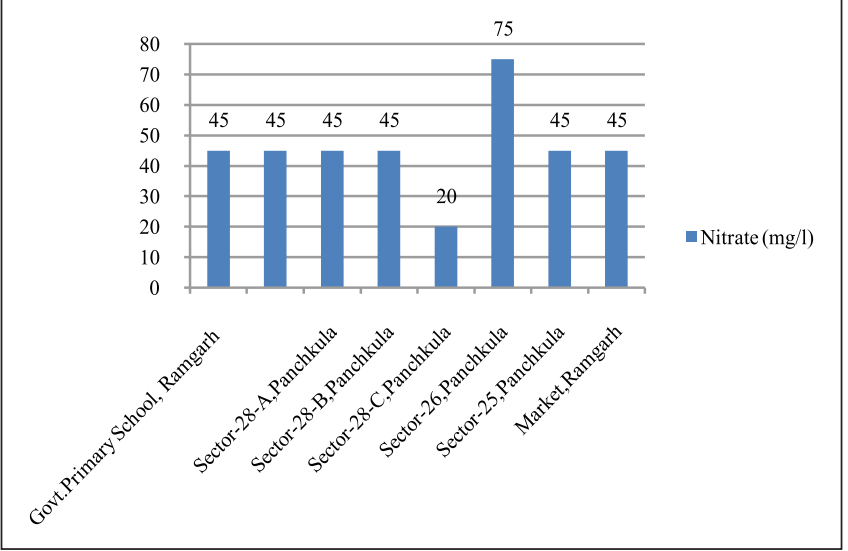

Figure 9: Nitrate in groundwater samples.

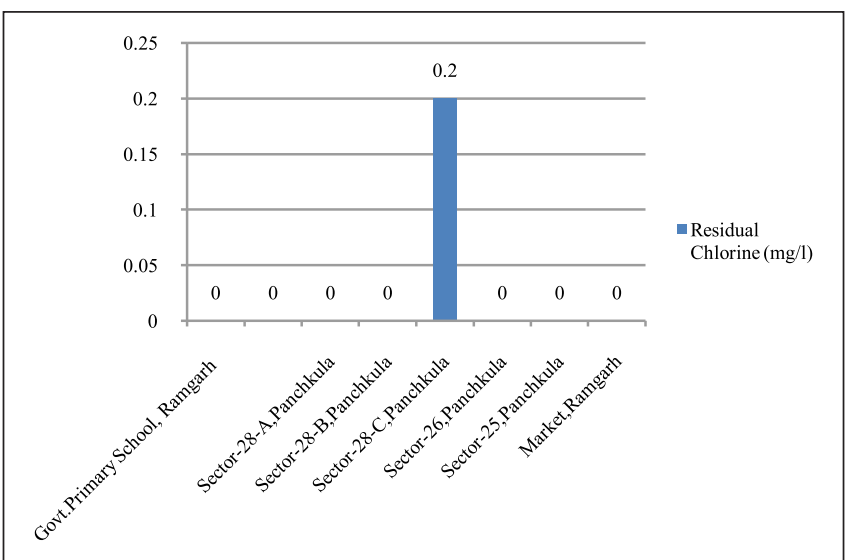

Figure 11: Residual Chlorine in groundwater samples.

Groundwater quality at Sector-26, Panchkula

In groundwater sample collected at Sector-26, Panchkula the chemical drinking water parameters were under limited to desirable values and ammonia, nitrate were proper for nonpotable drinking water (Fig.16).

Groundwater quality at Sector-28-A, Panchkula

In groundwater sample collected at Sector-28-A, Panchkula the different drinking water parameters were found to be

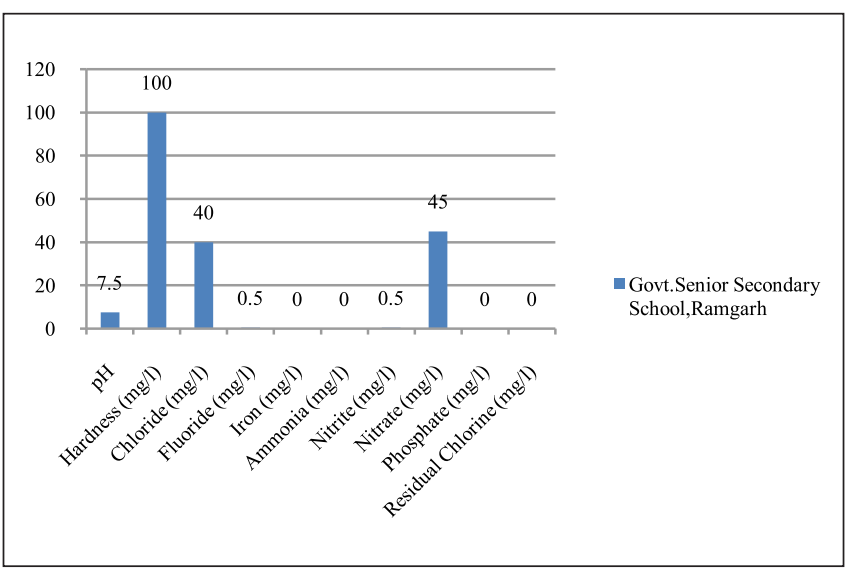

Fig.13: Groundwater quality at Govt. Senior Secondary School, Ramgarh 


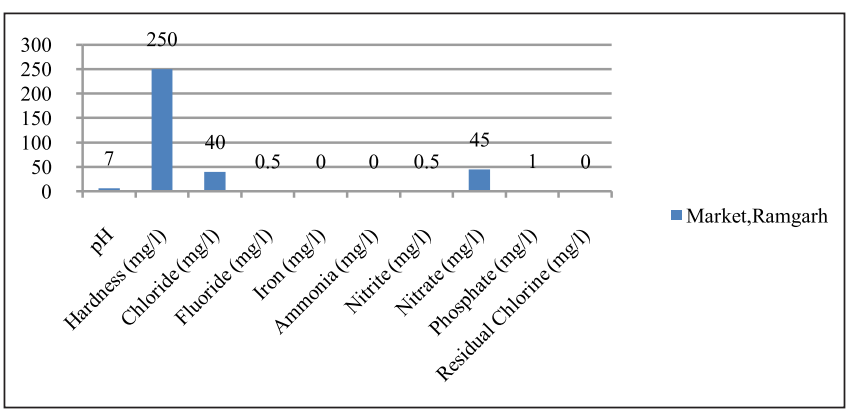

Figure 14:Groundwater quality at Market, Ramgarh.

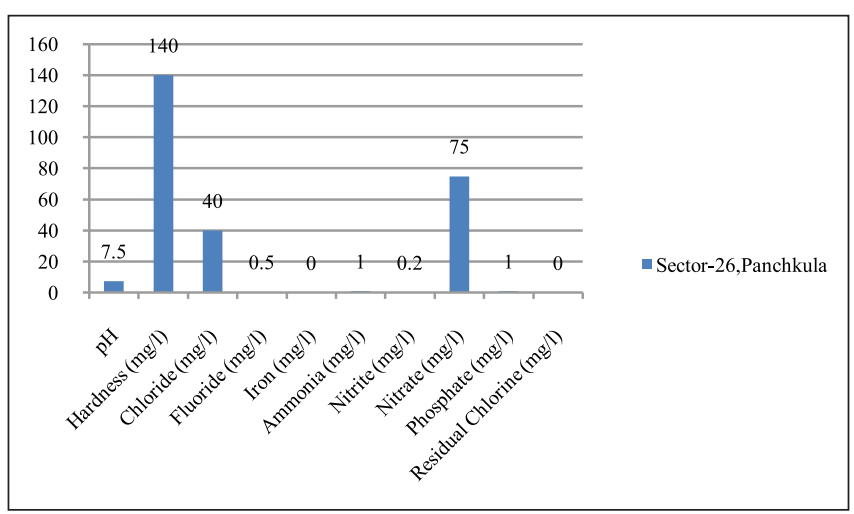

Figure 16: Groundwater quality at Sector-26, Panchkula.

desirable and hardness was permissible for drinking water purposes (Fig.17).

\section{Groundwater quality at Sector-28-B, Panchkula}

In groundwater sample collected at Sector-28-B, Panchkula,the chemical drinking water parameters $\mathrm{pH}$, chloride, fluoride, iron, ammonia, nitrite, nitrate, phosphate, residual chlorine were found to be within desirable limit and hardness under permissible drinking water limit (Fig.18).

Groundwater quality at Sector-28-C, Panchkula In groundwater sample collected at Sector-28-C, Panchkula, the drinking water parameters analyzed viz. $\mathrm{pH}$, hardness, chloride, fluoride, iron, ammonia, nitrite, nitrate, phosphate, residual chlorine were under desirable limit (Fig.19).

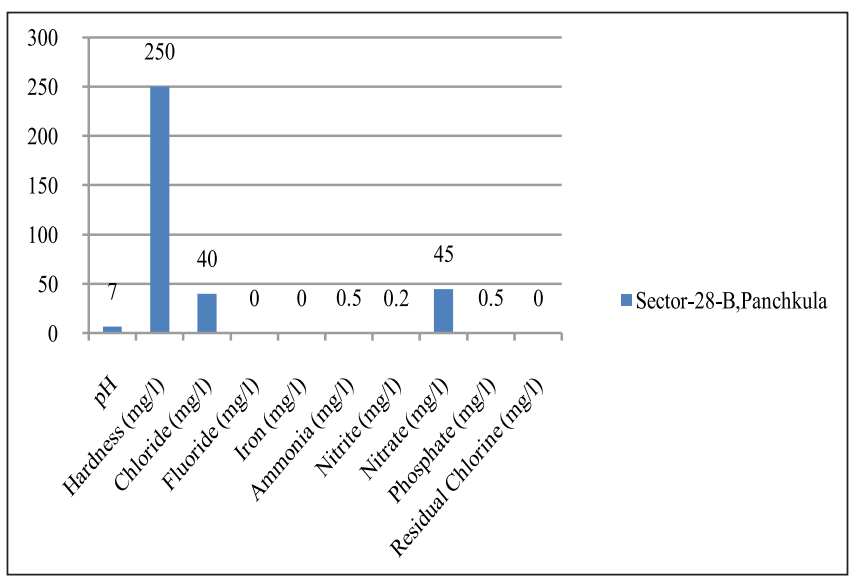

Figure 18: Groundwater quality at Sector-28-B, Panchkula.

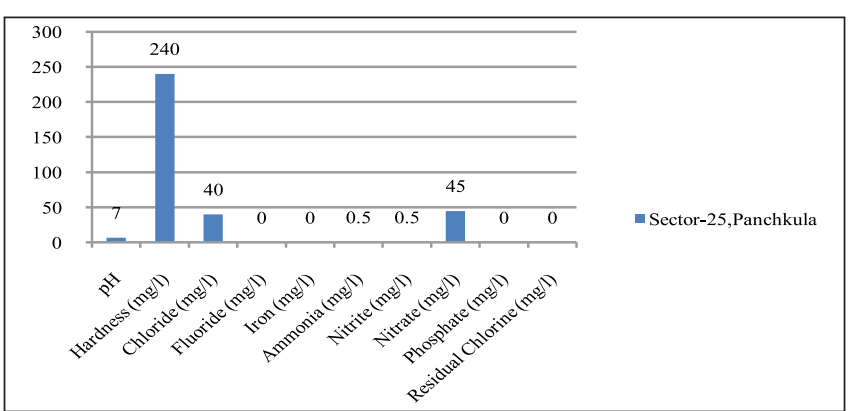

Figure 15: Groundwater quality at Sector-25, Panchkula.

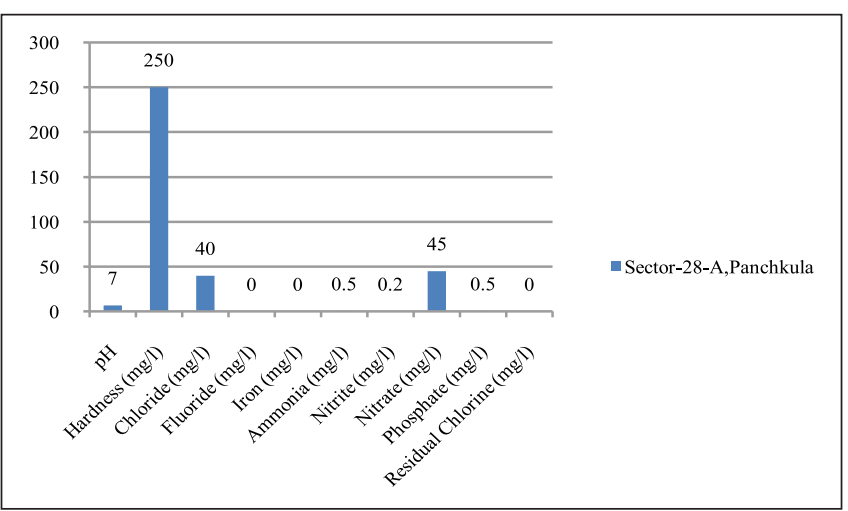

Figure 17: Groundwater quality at Sector-28-A, Panchkula.

\section{Conclusion}

In the study area, for all the eight groundwater samples $\mathrm{pH}$, chloride, fluoride, iron, nitrite, phosphate, residual chlorine were in desirable limits for drinking purpose. Hardness was desirable at Govt. Primary School, Ramgarh (180 mg/l), Govt. Senior Secondary School, Ramgarh (100 mg/l),Sector28,Panchkula (200 mg/l), Sector-26, Panchkula (140 mg/l) and permissible at Sector-28-A, Panchkula (250 mg/l), Sector-28-B, Panchkula (250 mg/l), Sector-25 (240 mg/l), Market, Ramgarh (250 mg/l). Ammonia was desirable atGovt. Primary School,Ramgarh $(0.5 \mathrm{mg} / \mathrm{l})$, Govt. Senior Secondary School, Ramgarh (nil), Sector- 28-A, Panchkula (0.5 mg/l), Sector-28-B, Panchkula (0.5 mg/l), Sector-25, Panchkula (0.5 mg/l), Market Ramgarh (nil) and non-potable

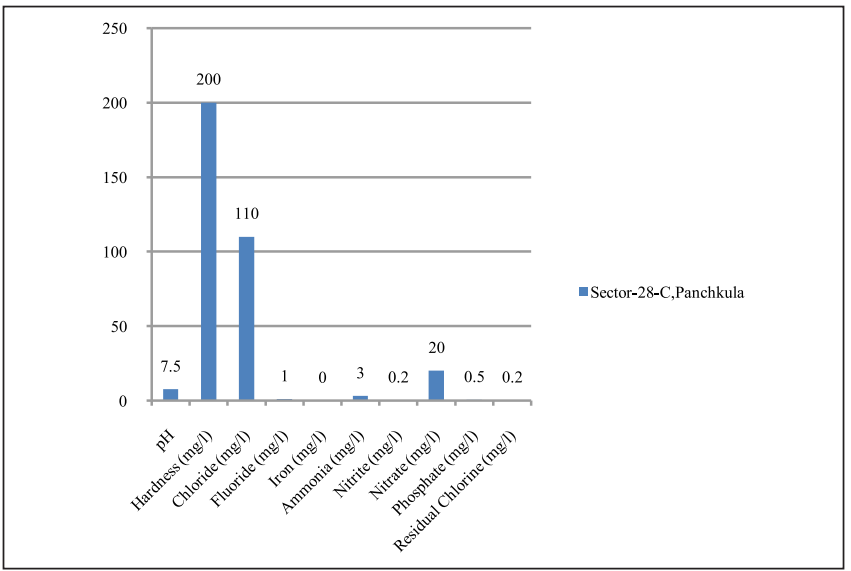

Figure 19: Groundwater quality at Sector-28-C, Panchkula. 
at Sector-28-C, Panchkula (3.0 mg/l) and Sector26,Panchkula (1 $\mathrm{mg} / \mathrm{l})$.Nitrate was desirable in seven groundwater samples and non-potable $(75 \mathrm{mg} / \mathrm{l})$ in one groundwater sample (Sector-26, Panchkula). Groundwater quality at Govt. Primary School, Ramgarh, Govt. Senior Secondary School, Ramgarh and Sector-28-C, Panchkula was desirable, at Market Ramgarh, Sector-25, Panchkula, Sector-28-A, Panchkula, Sector-28-B, Panchkula was permissible and Sector-26, Panchkula was found as nonpotable. The data from the present study is highly useful for monitoring the groundwater quality in the study area and will serve as a reference for further related surveys.

\section{References}

1. Abbulu Y, Rao GV. A study on physico-chemical characteristics of groundwater in the industrial zone of Visakhapatnam, Andhra Pradesh. American Journal of Engineering Research (AJER). 2013;2(10):112-6.

2. Agrawal R. A study of physico-chemical parameters of groundwater quality of Dudu town in Rajasthan. Indian Journal of Remote Sensing. 2009;2(4):969-71.
3. Deshpande SM, Aher, KR. Evaluation of groundwater quality and its suitability for drinking and agriculture use in parts of Vaijapur, District Aurangabad, India. Research Journal of Chemical Sciences. 2012;2 (1):2531.

4. Madhav S, Ahamad A, Kumar A, Kushawaha J, Singh P, Mishra PK. Geochemical assessment of groundwater quality for its suitability for drinking and irrigation purpose in rural areas of Sant Ravidas Nagar (Bhadohi), Uttar Pradesh. Geology, Ecology, and Landscapes. 2018; 2(2):127-36.

5. Tripathi AK, Mishra UK, Mishra A, Tiwari S, Dubey P. Studies of hydrogeochemical in groundwater quality around Chakghat area, Rewa District,Madhya Pradesh, India. International Journal of Modern Engineering Research.2012; 2 (6):4051-4059.

6. Zidi C, Jamrah A, Al-Issai L. Assessment of groundwater quality in Al-Buraimi, Sultanate of Oman. Journal of Materials and Environmental Sciences. 2017;8(4):1266-1276. 